\title{
Commercial Bank Balance Sheets Rebalanced
}

\section{Edward Nelson}

$\mathrm{U}$ nited States Treasury bill rates have declined to below 1 percent, and the spread between those rates and the federal funds rate has widened. Both effects are evidence of financial institutions' "flight to safety" since the subprime crisis hit financial markets in August 2007. By bidding away very liquid Treasuries from households and other firms, financial institutions have put upward pressure on the prices-and thus downward pressure on the yields-of these short-term Treasuries.

One anomalous aspect of this flight to safety is that, unlike other financial institutions, depository institutions (commercial banks) have not been increasing their holdings of Treasuries over the past several months (see upper chart). ${ }^{1}$ Moreover, commercial bank holdings of Treasuries have not risen as a proportion of their aggregate balance sheet, which is shown by expressing these assets as a percentage of banks' total (M2) deposit liabilities.

Commercial banks on the whole have not flocked to U.S. government securities, in part, because new developments oblige them to move more of their off-balance-sheet activities onto their balance sheet; as a result, commercial banks have taken on non-government securities formerly held by other institutions. For example, Chairman Bernanke has noted that many banks initially served in underwriting or advisory roles for subprime mortgage arrangements overseen by other institutions: "As the problems with these facilities multiplied," he observed, "banks came under increasing pressure to rescue the investment vehicles they sponsored... by taking the assets of the off-balance-sheet vehicles onto their own balance sheets."2

In short, commercial banks have dramatically increased their holdings of "other" (non-Treasury) securities and in turn have had to reduce their holdings of Treasuries to make room for this accumulation (see lower chart). So, the increase in Treasury holdings in the financial system from August 2007 to March 2008 was predominantly due to purchases by non-depository U.S. financial institutions and foreign financial institutions. It remains to be seen what

\section{U.S. Government Securities Held by Commercial Banks}

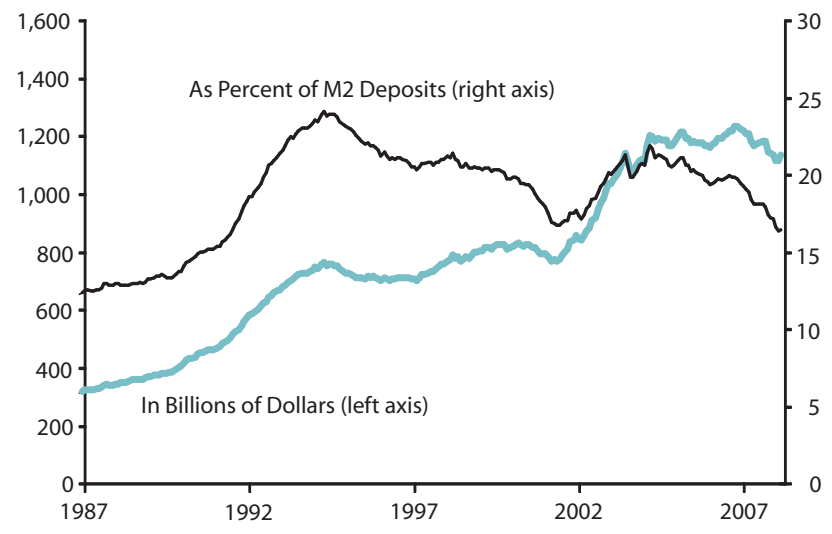

Other Securities Held by Commercial Banks

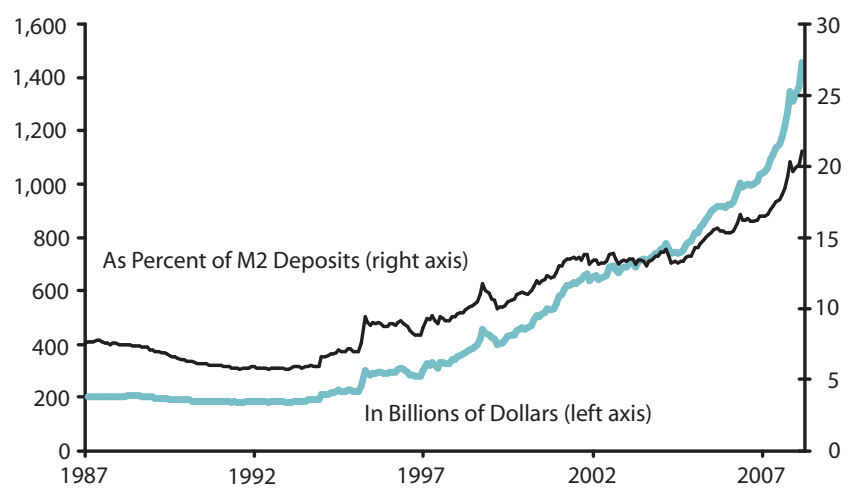

effect this rebalancing will have on commercial banks' investment and lending policies in the longer term.

\footnotetext{
${ }^{1}$ The series in the charts are at http://research.stlouisfed.org/fred2/data/ USGSEC.txt and http://research.stlouisfed.org/fred2/data/OTHSEC.txt.

2 Bernanke, Ben S. "Financial Markets, the Economic Outlook, and Monetary Policy," January 10, 2008; www.federalreserve.gov/newsevents/speech/ bernanke20080110a.htm.
} 